\title{
After Damage of Large Bile Ducts by Gamma-Aminobutyric Acid, Small Ducts Replenish the Biliary Tree by Amplification of Calcium-Dependent Signaling and de Novo Acquisition of Large Cholangiocyte Phenotypes
}

\author{
Romina Mancinelli, ${ }^{* \dagger \ddagger}$ Antonio Franchitto, ${ }^{\ddagger}$ \\ Eugenio Gaudio, ${ }^{\ddagger}$ Paolo Onori, $\$$ \\ Shannon Glaser, ${ }^{* \dagger}$ Heather Francis, ${ }^{+\dagger ष ा}$ \\ Julie Venter, ${ }^{\star \dagger}$ Sharon DeMorrow, ${ }^{* \dagger}$ \\ Guido Carpino," Shelley Kopriva, ${ }^{* \dagger}$ \\ Mellanie White, ${ }^{* \dagger}$ Giammarco Fava, ${ }^{* \star}$ \\ Domenico Alvaro, ${ }^{\dagger \dagger}$ and Gianfranco Alpini* ${ }^{\star \dagger \neq}$ \\ From the Scott \& White Digestive Disease Research Center," Temple, \\ Texas; the Department of Medicine, Division of Gastroenterology, ${ }^{\dagger}$ \\ Texas AGM Health Science Center, College of Medicine, Temple, \\ Texas; the Department of Human Anatomy, ${ }^{\ddagger}$ University of Rome "La \\ Sapienza," Rome, Italy; Experimental Medicine, ${ }^{\S}$ University of \\ L'Aquila, L'Aquila, Italy; the Division of Research and Education," \\ Scott \& White, Temple, Texas; the Department of Health Science," \\ University of Rome "Foro Italico," Italy; the Department of \\ Gastroenterology,* University Politecnica delle Marche, Ancona, \\ Italy; the Department of Gastroenterology," Polo Pontino, University \\ of Rome "La Sapienza," Rome, Italy; and the Department of \\ Research, ${ }^{\#}$ Central Texas Veterans Health Care System, Temple, \\ Texas
}

Large cholangiocytes secrete bicarbonate in response to secretin and proliferate after bile duct ligation by activation of cyclic adenosine $3^{\prime}, 5^{\prime}$-monophosphate signaling. The $\mathrm{Ca}^{2+}$-dependent adenylyl cyclase 8 (AC8, expressed by large cholangiocytes) regulates secretininduced choleresis. $\mathrm{Ca}^{2+}$-dependent protein kinase $\mathrm{C}$ (PKC) regulates small cholangiocyte function. Because $\gamma$-aminobutyric acid (GABA) affects cell functions by activation of both $\mathrm{Ca}^{2+}$ signaling and inhibition of $\mathrm{AC}$, we sought to develop an in vivo model characterized by large cholangiocyte damage and proliferation of small ducts. Bile duct ligation rats were treated with GABA for one week, and we evaluated: $\mathbf{G A B A}_{A}$, $\mathbf{G A B A}_{\mathrm{B}}$, and $\mathrm{GABA}_{C}$ receptor expression; intrahepatic bile duct mass (IBDM) and the percentage of apoptotic cholangiocytes; secretin-stimulated choleresis; and extracellular signal- regulated kinase1/2 (ERK1/2) phosphorylation and activation of $\mathrm{Ca}^{2+-}$ dependent PKC isoforms and AC8 expression. We found that both small and large cholangiocytes expressed GABA receptors. GABA: (i) induced apoptosis of large cholangiocytes and reduced large IBDM; (ii) decreased secretin-stimulated choleresis; and (iii) reduced ERK1/2 phosphorylation and AC8 expression in large cholangiocytes. Small cholangiocytes: (i) proliferated leading to increased IBDM; (ii) displayed activation of PKC $\beta$ II; and (iii) de novo expressed secretin receptor, cystic fibrosis transmembrane regulator, $\mathrm{Cl}^{-} / \mathrm{HCO}_{3}^{-}$anion exchanger 2 and AC8, and responded to secretin. Therefore, in pathologies of large ducts, small ducts replenish the biliary epithelium by amplification of $\mathrm{Ca}^{2+}$. dependent signaling and acquisition of large cholangiocyte phenotypes. (Am J Pathol 2010, 176:1790-1800; DOI: 10.2353/ajpatb.2010.090677)

Cholangiocytes line the intrahepatic biliary tree, ${ }^{1,2}$ a network of interconnecting ducts of different sizes and functions. ${ }^{1,2}$ A number of gastrointestinal hormones including secretin modify bile of canalicular origin before reaching the duodenum. ${ }^{3,4}$ In humans, cholangiocytes are the target cells in a number of chronic cholestatic liver diseases characterized by biliary proliferation/loss. ${ }^{5}$ Cholangio-

Supported in part by the Dr. Nicholas C. Hightower Centennial Chair of Gastroenterology from Scott \& White, the VA Research Scholar Award, a VA Merit Award, and National Institutes of Health grants DK58411, DK062975, and DK76898 (to G.A.), a National Institutes of Health K01 grant award (DK078532; to S.D.), and by University funds (to P.O.) and PRIN 2007 and Federate Athenaeum funds from University of Rome "La Sapienza" (to E.G.).

R.M. and A.F. contributed equally to this work.

Accepted for publication December 7, 2009.

Address reprint requests to Gianfranco Alpini, Ph.D., Texas A \& M Health Science Center, Medical Research Building, 702 SW H.K. Dodgen Loop, Temple, TX, 76504. E-mail: galpini@tamu.edu or galpini@medicine. tamhsc.edu 
cytes proliferate or are damaged in animal models of cholestasis including bile duct ligation (BDL) or acute administration of carbon tetrachloride $\left(\mathrm{CCl}_{4}\right)^{4,6-8}$ Secretin receptor (SR, expressed only by large cholangiocytes in rodent liver) $)^{1,2,8,9}$ is a unique pathophysiological tool for evaluating at the functional level the degree of biliary growth/loss. ${ }^{6-9}$ Whereas enhanced cholangiocyte growth is associated with increased SR expression and secretin-stimulated choleresis, biliary damage leads to decreased functional expression of SR. ${ }^{7,8}$

The human and rodent biliary epithelium is morphologically and functionally heterogeneous. ${ }^{1,2,10-12}$ In rat liver, purified small cholangiocytes $(\approx 8 \mu \mathrm{m}$ in size) derive from small ducts ( $<15 \mu \mathrm{m}$ in diameter), whereas large cholangiocytes $(\approx 15 \mu \mathrm{m}$ in size) originate from large ducts (>15 $\mu \mathrm{m}$ in diameter). ${ }^{1,2}$ Whereas the secretory, apoptotic, and proliferative activities of large cholangiocytes are regulated by changes in cyclic adenosine $3^{\prime}, 5^{\prime}$-monophosphate (CAMP)-dependent signaling, ${ }^{1,6,8,9,11,13}$ the function of small cholangiocytes (normally mitotically dormant) ${ }^{6,8}$ is regulated by the D-myo-inositol 1,4,5-trisphosphate $\left(\mathrm{IP}_{3}\right) / \mathrm{Ca}^{2+} /$ calmodulin-dependent protein kinase I signaling pathway. ${ }^{14,15}$ For example, large (but not small) rodent cholangiocytes express $\mathrm{SR},{ }^{1,2,10}$ cystic fibrosis transmembrane regulator (CFTR), ${ }^{1,2,10}$ and $\mathrm{Cl}^{-} / \mathrm{HCO}_{3}^{-}$ exchanger ${ }^{1,2,10}$ (recently identified as the $\mathrm{Cl}^{-} / \mathrm{HCO}_{3}^{-}$anion exchanger 2 [AE2]), ${ }^{16}$ and secrete bile in response to secretin by activation of $C A M P \Rightarrow$ protein kinase $A$ $(\mathrm{PKA}) \Rightarrow \mathrm{CFTR} \Rightarrow \mathrm{Cl}^{-} / \mathrm{HCO}_{3}^{-}$anion $\mathrm{AE2}$. $^{1,2,9} \mathrm{The} \mathrm{Ca}^{2+}$-dependent adenylyl cyclase 8 (AC8, expressed mainly by large cholangiocytes $)^{17}$ regulates secretin-stimulated choleresis of large bile ducts. ${ }^{17}$ After BDL, large but not small cholangiocytes undergo mitosis (leading to enhanced large duct mass) $)^{6,8,18}$ by activation of CAMP signaling. ${ }^{6,8,18} \mathrm{~A}$ single dose of $\mathrm{CCl}_{4}$ to rats induces a functional loss of large cAMP-responsive cholangiocytes, whereas small cholangiocytes (resistant to $\mathrm{CCl}_{4}$-induced apoptosis) de novo proliferate to compensate for the loss of large biliary mass. ${ }^{8}$ Although some studies suggest that activation of $\mathrm{Ca}^{2+}$-dependent signaling may be important in the regulation of small cholangiocyte function, ${ }^{14,15}$ the mechanisms by which small cholangiocytes replenish the biliary tree in response to the damage of large bile ducts is unknown.

Gamma-aminobutyric acid (GABA) is the chief inhibitory neurotransmitter in the vertebrate central nervous system. ${ }^{19}$ In addition to the central nervous system, the liver represents the major site of synthesis and metabolism of GABA. ${ }^{20}$ GABA actions are mediated by three GABA receptor subtypes $\left(G_{A B A}, G A B A_{B}\right.$, and $\left.G_{A B A}\right){ }^{21}$ Studies have shown that GABAergic activity inhibits hepatic regeneration after partial hepatectomy in rats. ${ }^{22}$ We have shown that GABA decreases both in vivo and in vitro cholangiocarcinoma growth. ${ }^{21}$ However, no data exist regarding the role of GABA in the regulation of cholangiocyte hyperplasia in cholestasis. Because GABA can affect cell functions by both activation of $\mathrm{Ca}^{2+}$ signaling and inhibition of $\mathrm{AC}$ activity, ${ }^{23}$ we tested the hypothesis that GABA regulates the proliferative, apoptotic, and secretory activities of small and large cholangiocytes by the differential activation/deactivation of $\mathrm{Ca}^{2+}$ - and CAMPdependent signaling pathways.

\section{Materials and Methods}

\section{Materials}

Reagents were purchased from Sigma Chemical Co. (St. Louis, MO) unless otherwise indicated. The RIA kits for the measurement of intracellular CAMP ([ ${ }^{125}$ I] Biotrak Assay System, RPA509) and IP ${ }_{3}$ (D-myo-inositol 1,4,5trisphosphate $\left(\mathrm{IP}_{3}\right)\left[{ }^{3} \mathrm{H}\right]$ Biotrak Assay System, TRK1000) levels were purchased from GE Health care (Piscataway, $\mathrm{NJ}$ ). The antibodies were obtained from Santa Cruz Biotechnology, Inc. (Santa Cruz, CA) unless otherwise indicated. The CFTR monoclonal (IgG1) antibody (M3A7, previously used by us in rodent cholangiocytes) ${ }^{10}$ was purchased from Thermo Fisher Scientific (Fremont, CA). The antibody (an affinity-purified rabbit anti-rat AE2 IgG) against $\mathrm{Cl}^{-} / \mathrm{HCO}_{3}^{-} \mathrm{AE} 2^{16}$ was purchased from $\alpha$ Diagnostic International (San Antonio, TX). The RNeasy Mini Kit to purify total RNA from cholangiocytes was purchased from Qiagen Inc, Valencia, CA.

\section{Animal Models}

Male 344 Fischer rats (150 to $175 \mathrm{~g}$ ) were purchased from Charles River (Wilmington, MA) and kept in a temperature-controlled environment $\left(22^{\circ} \mathrm{C}\right)$ with a $12: 12$ hours light/dark cycle. Animals were fed ad libitum and had free access to drinking water. The studies were performed in normal rats, and in rats that immediately after $\mathrm{BDL}$ or bile duct incannulation (BDI, for bile collection) ${ }^{4}$ were treated with daily IP injections of $\mathrm{NaCl}$ or GABA (50 mg/kg body weight) ${ }^{24}$ for 1 week. Before each procedure, animals were anesthetized with sodium pentobarbital $(50 \mathrm{mg} / \mathrm{kg}$ IP) according to the regulations of the panel on euthanasia of the American Veterinarian Medical Association and local authorities. In all animals, we measured wet liver weight, body weight, and wet liver weight to body weight ratio, an index of liver cell growth including cholangiocytes. ${ }^{4}$

\section{Purification of Small and Large Cholangiocytes}

Virtually pure (by $\gamma$-glutamyl transpeptidase histochemistry) ${ }^{25}$ and distinct subpopulations of small (mean diameter $8 \mu \mathrm{m}$ ) and large (mean diameter $14 \mu \mathrm{m})$ cholangiocytes $^{2,9}$ were isolated by counterflow elutriation. ${ }^{2,6,9}$ Cell viability was approximately $98 \%$.

\section{Expression of $G A B A_{A}, G A B A_{B}$, and $G A B A_{C}$ Receptors}

The expression of GABA receptors was evaluated by: (i) immunohistochemistry in paraffin-embedded liver sections (4 to $5 \mu \mathrm{m}$ thick) from the aforementioned groups of animals; and (ii) immunofluorescence in cell smears of purified small and large BDL cholangiocytes. For immu- 
nohistochemistry, ${ }^{26}$ endogenous peroxidase activity was blocked by a 30-minute incubation in methanolic hydrogen peroxide (2.5\%). The endogenous biotin was blocked by Biotin Blocking System (Dako, Copenhagen, Denmark) according to the instructions supplied by the vendor. Sections were hydrated in graded alcohol and rinsed in PBS ( $\mathrm{pH}$ 7.4), then the primary antibodies GABA $_{A}$ (Santa Cruz, \#21336; 1: 50 dilution), GABA

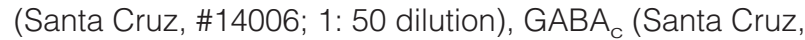
\#23362; 1: 50 dilution) were applied and incubated overnight at $4^{\circ} \mathrm{C}$. Samples were rinsed with PBS for 5 minutes, incubated for 10 minutes at room temperature with secondary biotinylated antibody (Dako LSAB Plus System, Milan, Italy), then with Dako ABC (Dako LSAB Plus System, Milan, Italy) and finally developed with 3-3' diaminobenzidine. To demonstrate the specificity of the immunoreactions, negative controls (the primary antibody was replaced with the same dilution - with normal serum from the same species) were performed for all immunoreactions. Sections were analyzed in a coded manner using a BX-51 light microscope (Olympus, Tokyo, Japan) with a video cam (Spot Insight; Diagnostic Instrument, Inc., Sterling Heights, MI) and processed with an Image Analysis System (IAS: Delta Sistemi, Rome, Italy). Immunofluorescence for GABA receptors was performed as described. ${ }^{27}$ After staining, images were visualized using an Olympus IX-71 confocal microscope. For all immunoreactions, negative controls were included.

To evaluate the message expression of $G_{A B A}$, $G A B A_{B}$, and $G A B A_{C}$ in purified small and large cholangiocytes, we used the $\mathrm{RT}^{2}$ Real-Time assay from SABiosciences (Frederick, MD). ${ }^{14} \mathrm{~A} \Delta \Delta \mathrm{C}_{\mathrm{T}}$ (delta delta of the threshold cycle) analysis was performed using brain tissue as the control sample. ${ }^{14}$ The primers (purchased from SABiosciences) for $G_{A B A}, G A B A_{B}$, and $G A B A_{C}$ were designed according to the NCBI GenBank Accession number, NM 017289 for $\mathrm{GABA}_{A}{ }^{28}$; NM 031028 for $\mathrm{GABA}_{B}{ }^{29}$; and NM 017291 for GABA ${ }_{C}{ }^{30}$ Data were expressed as relative mRNA levels \pm SEM of GABA receptors to glyceraldehyde-3-phosphate dehydrogenase (GAPDH) ratio.

\section{In Vivo Effect of GABA on Liver Morphology, Cholangiocyte Apoptosis, and Proliferation}

We evaluated lobular morphology, necrosis, and portal inflammation by hematoxylin \& eosin staining of paraffinembedded liver sections ( 4 to $5 \mu \mathrm{m}$ thick). Liver sections were examined in a coded fashion by BX-51 light microscopy (Olympus, Tokyo, Japan) equipped with a camera. Six slides were analyzed for each group and six nonoverlapping fields (magnification $\times 20$ ) for each slide were evaluated for each parameter.

Apoptosis of small and large cholangiocytes was measured by quantitative terminal deoxynucleotidyl transferase biotin-dUTP nick end labeling (TUNEL) kit (Apoptag; Chemicon International, Inc) in liver sections (4 to $5 \mu \mathrm{m}$ thick) from $\mathrm{BDL}$ rats treated with $\mathrm{NaCl}$ or GABA. Six slides were analyzed for each group using a BX-51 light microscopy (Olympus, Tokyo, Japan). Positive cholangiocytes were counted in six nonoverlapping fields (magnification $\times 20)$ for each slide, and the data are expressed as percentage of positive cells.

Immunoblots for BCL2-associated $\mathrm{X}$ protein (Bax, a pro-apoptotic protein) ${ }^{31}$ expression was performed in protein $(10 \mu \mathrm{g})$ from whole cell lysates from small and large cholangiocytes. Blots were normalized by $\beta$-actin. ${ }^{14}$ The intensity of the bands was determined by scanning video densitometry using the phospho-imager, Storm 860, (GE Health care, Piscataway, NJ) and the ImageQuant TL software version 2003.02 (GE Health care, Little Chalfont, Buckinghamshire, England).

Proliferation of small $(<15 \mu \mathrm{m} \text { diameter })^{1}$ and large $(>15 \mu \mathrm{m} \text { diameter })^{1}$ bile ducts was measured by evaluating intrahepatic bile duct mass (IBDM) in liver sections. IBDM was measured as area occupied by cytokeratin-19 positive-bile duct/total area $\times 100$. Proliferation was evaluated by immunoblots for proliferating cellular nuclear antigen (PCNA) in protein $(10 \mu \mathrm{g})$ from whole cell lysate from purified small and large cholangiocytes. Blots were normalized to $\beta$-actin ${ }^{14}$ and visualized as described above.

\section{Membrane Translocation and Phosphorylation of $\mathrm{Ca}^{2+}$-Dependent PKC Isoforms (Expression of CAMP-Dependent Signaling)}

We next determined whether small BDL cholangiocytes proliferate and secrete (to compensate for GABA-induced damage of large CAMP-dependent BDL cholangiocytes) by both: (i) the activation of $\mathrm{Ca}^{2+}$-dependent signaling evaluated by the enhanced translocation and phosphorylation of $\mathrm{Ca}^{2+}$-dependent protein kinase $\mathrm{C}$ (PKC) isoforms (ie, $\alpha \mathrm{l}, \beta \mathrm{l}, \beta \mid \mathrm{l}$ and $\gamma$ ), which are important in the regulation of cholangiocyte function ${ }^{7,32,33}$; and (ii) the de novo acquisition of CAMP-dependent phenotypes (ie, expression of SR, CFTR, $\mathrm{Cl}^{-} / \mathrm{HCO}_{3}^{-} \mathrm{AE} 2$ and AC8, and CAMP and $\mathrm{Cl}^{-}$efflux in response to secretin), which are key in the modulation of large cholangiocyte functions. ${ }^{1,2,6,8,9,13,34}$

The activation of $\mathrm{Ca}^{2+}$-dependent PKC $\alpha, \beta l, \beta \mathrm{II}$, or $\gamma$ was evaluated by: (i) immunofluorescence (membrane translocation) in cell smears; and (ii) immunoblots (phosphorylation $)^{7,14}$ in protein $(10 \mu \mathrm{g})$ from whole cell lysate from small and large cholangiocytes. In purified small and large cholangiocytes, we also evaluated the phosphorylation of ERK1/2 (expressed by a ratio to the corresponding total protein), ${ }^{18}$ a protein linked to CAMP-dependent signaling pathway. ${ }^{18}$

\section{Evaluation of Secretory Activity of Small and Large Cholangiocytes}

We performed experiments to demonstrate that following chronic GABA administration to BDL rats: (i) small cholangiocytes acquire functional phenotypes of large cholangiocytes; and (ii) there is down-regulation of CAMP-dependent secretory activity ${ }^{1,2,8,9}$ in large cholangiocytes. To achieve this, we measured the protein expression for $\mathrm{SR}, \mathrm{CFTR}$, and $\mathrm{Cl}^{-} / \mathrm{HCO}_{3}^{-} \mathrm{AE} 2$ by immunohistochemistry in liver sections (4 to $5 \mu \mathrm{m}$ thick), and 


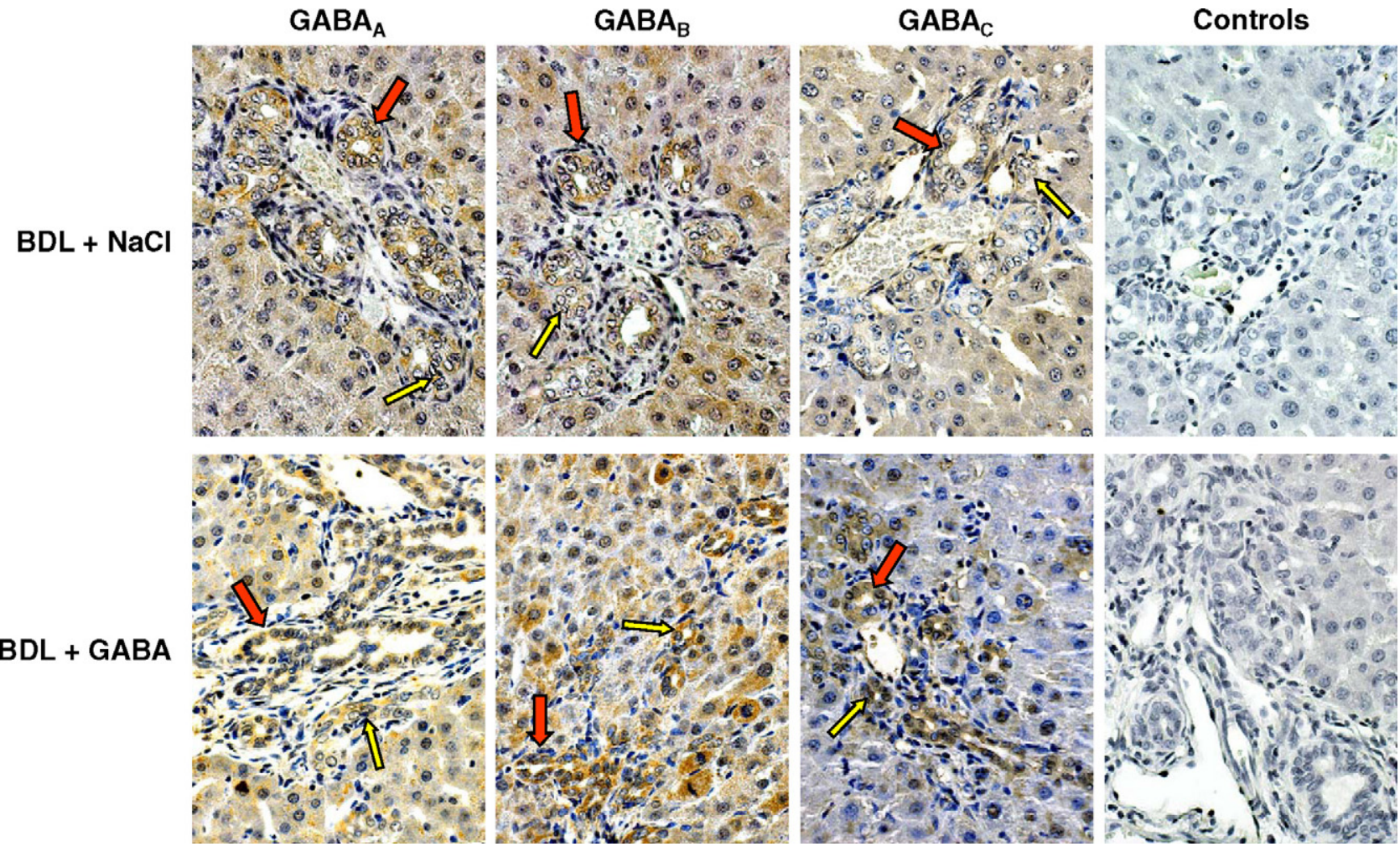

Figure 1. Representative immunohistochemistry for $\mathrm{GABA}_{\mathrm{A}}, \mathrm{GABA}_{\mathrm{B}}$, and $\mathrm{GABA}_{\mathrm{C}}$ in liver sections from $\mathrm{BDL}$ rats treated with NaCl or $\mathrm{GABA}$ for 1 week. Both small (yellow arrows) and large (red arrows) bile ducts express the three subtypes of GABA receptors. No staining was visible when primary antibodies were replaced with nonimmune serum from the same species. Original magnification, $\times 40$.

immunofluorescence ${ }^{14,27}$ in small and large cholangiocytes; (ii) AC8 protein expression in liver sections (4 to 5 $\mu \mathrm{m})$ by immunohistochemistry, ${ }^{14}$ and AC8 gene expression by real-time PCR in total RNA $(1 \mu \mathrm{g})$ from small and large cholangiocytes; and (iii) basal and secretin-stimulated CAMP levels by $\mathrm{RIA}^{6,7,13,34}$ and ${ }^{36} \mathrm{Cl}^{-}$efflux (a functional index of CFTR activity). ${ }^{9,35,36}$ The primers (purchased from SABiosciences, Frederick, MD) for AC8 were designed according to the NCBI GenBank Accession number NM 017142. ${ }^{37}$

The secretory activity of small and large cholangiocytes was also assessed by measuring basal and secretin-stimulated bile and bicarbonate secretion in bile fistula BDI rats. ${ }^{4}$ After anesthesia, rats were surgically prepared for bile collection as described. ${ }^{4}$ When steadystate bile flow was reached (60 to 70 minutes from the intravenous infusion of Krebs-Ringer-Henseleit solution, $\mathrm{KRH})$, rats were infused with secretin $(100 \mathrm{nmol} / \mathrm{L})$ for 30 minutes followed by IV infusion of $\mathrm{KRH}$ for 30 minutes. Bicarbonate concentration in bile was determined by an ABL 520 Blood Gas System (Radiometer Medical A/S, Copenhagen, Denmark).

\section{Statistical Analysis}

All data are expressed as mean \pm SEM. Differences between groups were analyzed by Student unpaired $t$ test when two groups were analyzed and analysis of variance when more than two groups were analyzed, followed by an appropriate post hoc test.

\section{Results}

\section{Cholangiocytes Express GABA Receptors}

Immunohistochemistry in liver sections from normal (not shown) and $\mathrm{BDL}$ (Figure 1) rats treated with $\mathrm{NaCl}$ or GABA shows that both small (yellow arrows) and large (red arrows) bile ducts express $G A B A_{A}, G A B A_{B}$, and $\mathrm{GABA}_{C}$ receptors. By immunofluorescence, there was positive immunoreactivity for the three GABA receptors in small and large BDL cholangiocytes (Figure 2A). Negative controls are shown in Figure 2A. By real-time PCR, both small and large cholangiocytes from $\mathrm{BDL}$ rats treated with $\mathrm{NaCl}$ or $\mathrm{GABA}$ express the message for the three $\mathrm{GABA}$ receptors (Figure $2 \mathrm{~B}$ ).

\section{Effect of GABA on Liver Histology, Liver and Body Weight, Apoptosis, and Proliferation of Small and Large Bile Ducts}

No significant differences in wet liver weight, body weight, liver to body weight ratio, degree of portal inflammation, necrosis, and lobular damage were observed in $\mathrm{BDL}$ rats treated with $\mathrm{NaCl}$ or GABA for 1 week (not shown). Chronic in vivo administration of GABA to normal rats did not alter cholangiocyte apoptosis or proliferation (not shown). Administration of GABA to BDL rats induced apoptosis of large bile ducts (red arrows, by TUNEL in liver sections) (Figure 3A and Table 1) and purified large 


\section{A Small BDL cholangiocytes}
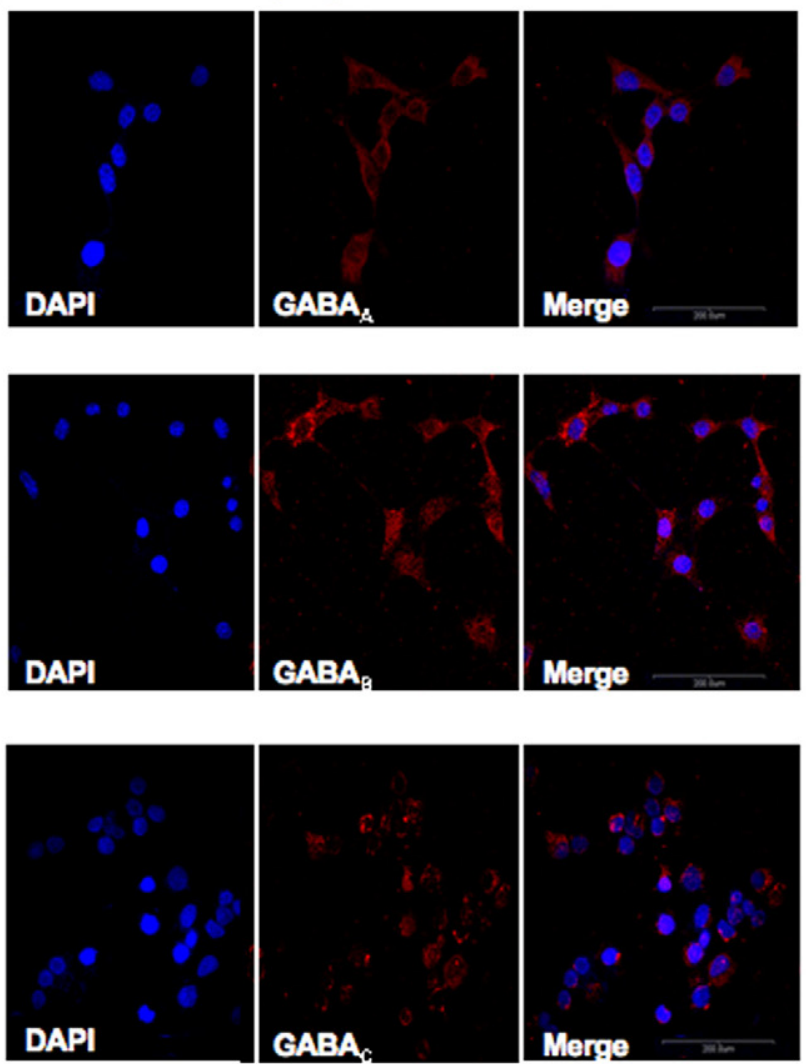

B

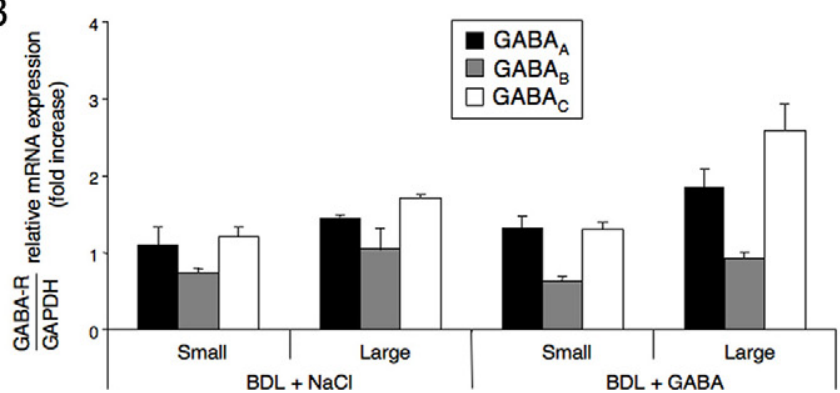

Large BDL cholangiocytes
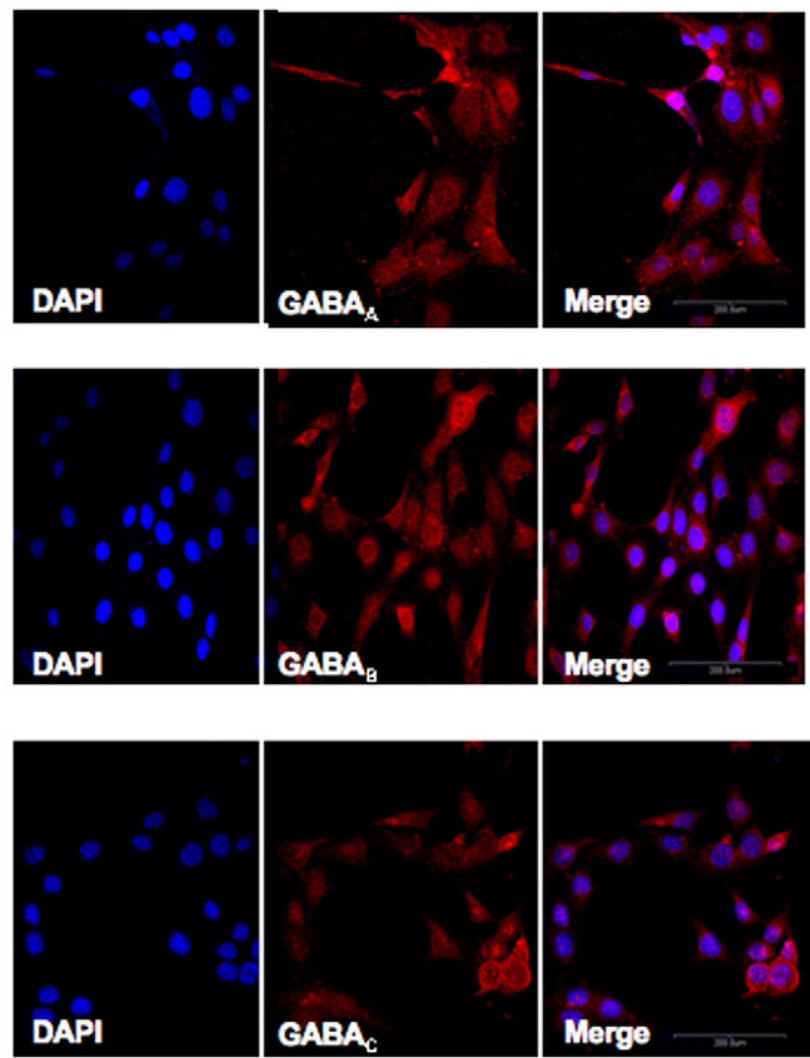

Figure 2. A: By immunofluorescence, both small and large cholangiocytes from BDL rats express the three GABA receptor subtypes. Specific immunoreactivity of representative fields is shown in red; cell nuclei were stained with DAPI (blue). Scale bar $=200 \mu \mathrm{m}$. B: Real-time PCR shows that purified small and large cholangiocytes from BDL rats treated with $\mathrm{NaCl}$ or GABA express the message for all three GABA receptors. Data are mean \pm SEM of 3 experiments.

cholangiocytes (by Bax immunoblots; Figure 3B). No changes in apoptosis were seen in small ducts (Figure $3 \mathrm{~A}$ ) and purified small cholangiocytes (Figure 3B) from $\mathrm{BDL}$ rats treated with $\mathrm{NaCl}$ or GABA.

In agreement with previous studies, ${ }^{6}$ after BDL only large cholangiocytes proliferated leading to increased large IBDM (Figure 4A and Table 1). Concomitant with GABA-induced apoptosis of large cholangiocytes (Figure $3, A$ and $B$ ), there was a significant decrease in large (red arrows) IBDM (Figure 4A and Table 1) and the de novo proliferation of small ducts (yellow arrows) leading to an increase in small IBDM (Figure 4A and Table 1). The overall IBDM was similar between the BDL rats treated with $\mathrm{NaCl}$ or GABA (Table 1). After BDL, large cholangiocytes displayed higher proliferative activity compared with small BDL cholangiocytes (Figure 4B)., ${ }^{6,8}$ Furthermore, there was decreased proliferation in large cholangiocytes and increased PCNA protein expression in purified small cholangiocytes from $B D L$ rats treated with
GABA compared with small and large cholangiocytes from $\mathrm{BDL}$ rats treated with $\mathrm{NaCl}$ (Figure 4B).

\section{Membrane Translocation and Phosphorylation of $\mathrm{Ca}^{2+}$-Dependent PKC Isoforms and Phosphorylation of ERK1/2}

We observed membrane translocation (by immunofluorescence, Figure 5A) and enhanced phosphorylation of $\mathrm{PKC} \beta \|$ (by immunoblots, Figure $5 \mathrm{~B}$ ) in small cholangiocytes from BDL GABA-treated rats compared with small cholangiocytes from BDL rats treated with $\mathrm{NaCl}$. No membrane translocation of $\mathrm{PKC} \alpha, \mathrm{PKC} \beta$ I, and $\mathrm{PKC} \gamma$ was observed in small cholangiocytes from BDL rats treated with GABA compared with small cholangiocytes from $\mathrm{BDL}$ rats treated with $\mathrm{NaCl}$ (not shown). After GABA administration to BDL rats, there was: (i) decreased phosphorylation of $\mathrm{ERK} 1 / 2$ in large cholangiocytes; 
A
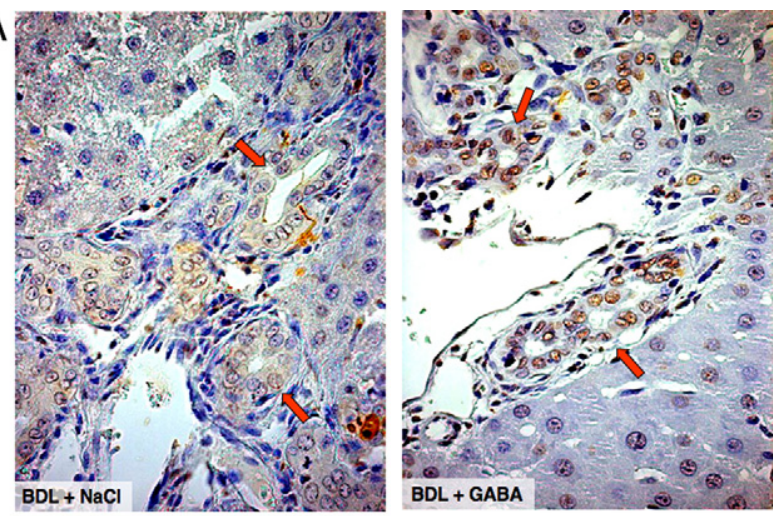

B

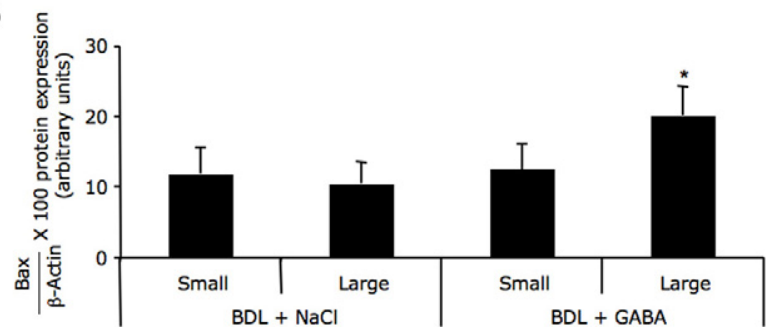

Figure 3. Evaluation of cholangiocyte apoptosis by TUNEL analysis in liver sections (A), and Bax immunoblots in small and large cholangiocytes (B) from BDL rats treated with $\mathrm{NaCl}$ or GABA for 1 week. GABA induced apoptosis of large ducts (A, red arrows, for quantitative data see Table 1) and large cholangiocytes (B) from BDL rats treated with GABA compared with $\mathrm{BDL}$ rats treated with $\mathrm{NaCl}$. A and $\mathbf{B}$ : No changes in apoptosis were seen in small ducts and small cholangiocytes from BDL rats treated with $\mathrm{NaCl}$ or GABA. A: Original magnification, $\times 40$. B: Data are mean \pm SEM of 8 blots. ${ }^{*} P<0.05$ versus large cholangiocytes from $\mathrm{BDL}$ rats treated with $\mathrm{NaCl}$ for 1 week.

and (ii) increased ERK2 (but not ERK1) phosphorylation in small cholangiocytes compared with small and large cholangiocytes from $\mathrm{BDL}$ rats treated with $\mathrm{NaCl}$ (Figure 5C).

Table 1. Evaluation of $\%$ of Tunel-Positive Cholangiocytes in Small and Large Bile Ducts and Measurement of Bile Duct Mass by Cytokeratin 19 Staining

\begin{tabular}{|c|c|c|c|}
\hline Groups & $\begin{array}{c}\text { Bile } \\
\text { ducts }\end{array}$ & Apoptosis & IBDM \\
\hline \multirow{2}{*}{$\underset{\mathrm{NaCl}}{\text { Normal }}+$} & Small & ND & $0.05 \pm 0.01$ \\
\hline & Large & ND & $0.21 \pm 0.03$ \\
\hline \multirow{2}{*}{$\begin{array}{c}\text { Normal + } \\
\text { GABA }\end{array}$} & Small & ND & $0.07 \pm 0.01$ \\
\hline & Large & ND & $0.19 \pm 0.02$ \\
\hline \multirow{2}{*}{$\begin{array}{l}\mathrm{BDL}+ \\
\mathrm{NaCl}\end{array}$} & Small & $12.04 \pm 2.77$ & $0.90 \pm 0.08$ \\
\hline & Large & $15.14 \pm 2.46$ & $4.65 \pm 0.34$ \\
\hline \multirow{2}{*}{$\begin{array}{l}\mathrm{BDL}+ \\
\mathrm{GABA}\end{array}$} & Small & $10.62 \pm 1.85$ & $1.70 \pm 0.15^{\dagger}$ \\
\hline & Large & $40.77 \pm 2.68^{*}$ & $2.61 \pm 0.31^{\ddagger}$ \\
\hline
\end{tabular}

Small bile ducts $=<15 \mu \mathrm{m}$ diameter; large bile ducts $=>15 \mu \mathrm{m}$ diameter. Apoptosis of small and large bile ducts was measured by TUNEL analysis in liver sections. Proliferation of small and large bile ducts was measured by evaluating intrahepatic bile duct mass (IBDM) in liver sections. IBDM was measured as area occupied by CK19-positive bile duct/total area $\times 100$. ND indicates not detected. Data are expressed as mean \pm SEM.

${ }^{*} P<0.05$ versus the number of large bile ducts (positive by TUNEL) from BDL rats treated with $\mathrm{NaCl}$.

${ }^{t} P<0.05$ versus the number of small bile ducts from BDL NaCltreated rats.

${ }^{\ddagger} P<0.05$ versus the number of large bile ducts from $\mathrm{BDL} \mathrm{NaCl}-$ treated rats.
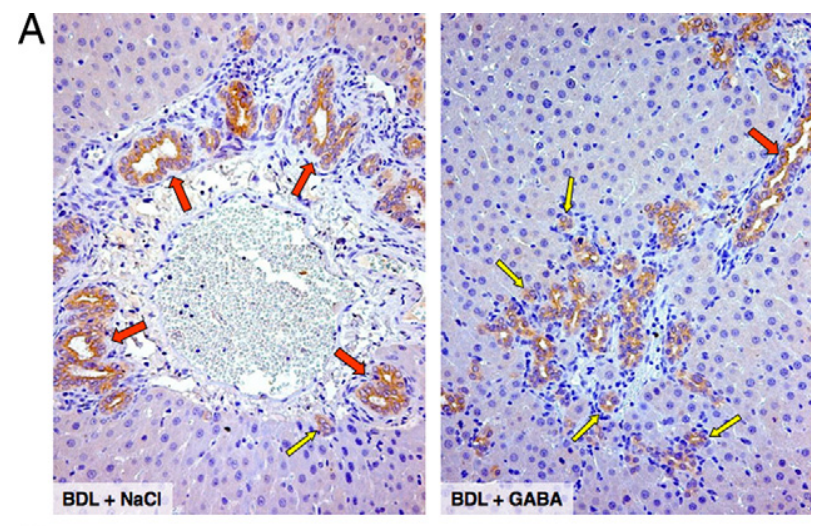

$\mathrm{B}$

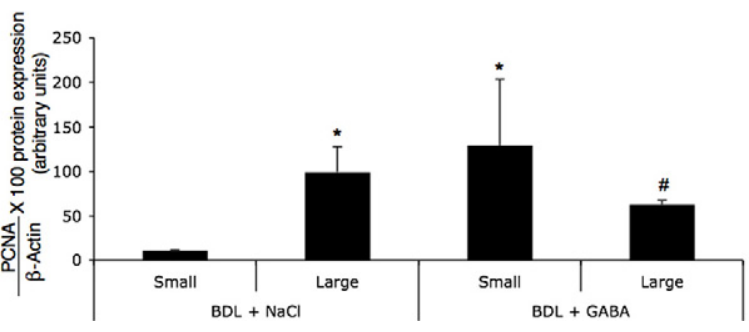

Figure 4. Measurement of IBDM of small and large bile ducts by immunohistochemistry for cytokeratin-19 in liver sections (A), and PCNA protein expression in protein $(10 \mu \mathrm{g})$ from whole cell lysate from small and large cholangiocytes (B) from BDL rats treated with $\mathrm{NaCl}$ or GABA for 1 week. A: After BDL, large (red arrows) bile ducts proliferate leading to an increase in large IBDM; there were no changes in the number of small (yellow arrow) bile ducts. After GABA administration, there were decreased large IBDM and the de novo proliferation of small bile ducts (yellow arrows) leading to an increase in small IBDM (for quantitative data see Table 1). Original magnification, $\times 20$. Data are mean \pm SEM of 36 cumulative values obtained from the six slides evaluated per each group of animals. B: After BDL, only large cholangiocytes displayed higher proliferative activity. There was decreased proliferation in large cholangiocytes and increased PCNA protein expression in purified small cholangiocytes from BDL rats treated with GABA compared with BDL rats treated with $\mathrm{NaCl}$. Data are mean \pm SEM of 8 blots. $* P<0.05$ versus small cholangiocytes from $\mathrm{BDL}$ rats treated with $\mathrm{NaCl}$ for 1 week. ${ }^{\#} P<$ 0.05 versus large cholangiocytes from BDL rats treated with $\mathrm{NaCl}$ for 1 week.

\section{Evaluation of Biliary Markers and Secretory Activity of Small and Large Cholangiocytes}

The protein for SR, CFTR, and $\mathrm{Cl}^{-} / \mathrm{HCO}_{3}^{-} \mathrm{AE} 2$ was expressed only by large bile ducts (red arrows, Figure 6A) and large cholangiocytes (by immunofluorescence, not shown $)^{1,2}$ from BDL rats. By immunofluorescence, small $\mathrm{BDL}$ cholangiocytes do not express SR, CFTR, and $\mathrm{Cl}^{-} /$ $\mathrm{HCO}_{3}^{-} \mathrm{AE2}$ (Figure 6A). In $\mathrm{BDL}$ rats treated with $\mathrm{GABA}$, small ducts (yellow arrows, Figure $6 \mathrm{~A}$ ) and small cholangiocytes (Figure 6A) express de novo SR, CFTR, and $\mathrm{Cl}^{-} / \mathrm{HCO}_{3}^{-}$AE2. Parallel to our previous studies, ${ }^{17} \mathrm{immu}-$ nohistochemistry in liver sections shows that AC8 was mostly expressed by large cholangiocytes from BDL rats treated with $\mathrm{NaCl}$ (Figure 6B). In liver sections from BDL rats treated with GABA, the expression of AC8 in liver sections seemed lower in large ducts and present de novo in small bile ducts (Figure 6B). Similarly, by real-time PCR we demonstrated that: (i) AC8 was present in large and at lower levels in small BDL cholangiocytes ${ }^{17}$; and (ii) AC8 mRNA expression decreased in large cholangiocytes and significantly increased in small cholangiocytes from $\mathrm{BDL}$ rats treated with GABA (Figure 6B). 
A

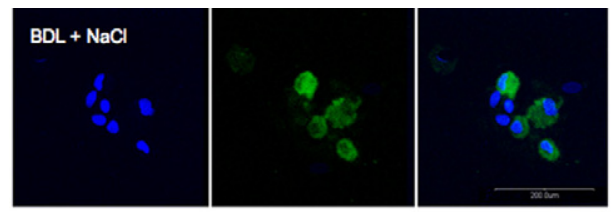

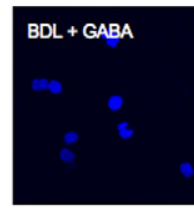

DAPI

B

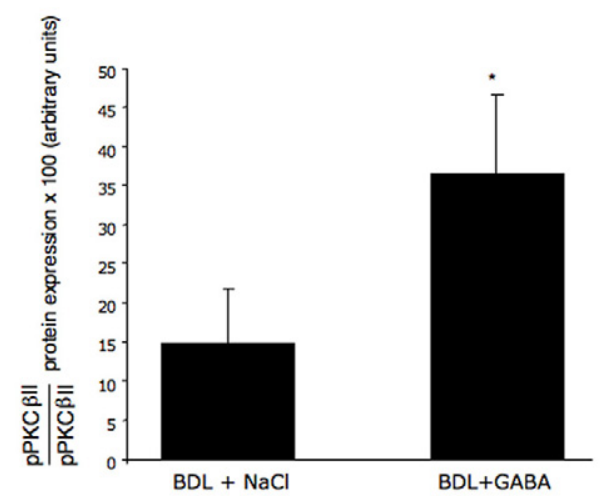

C

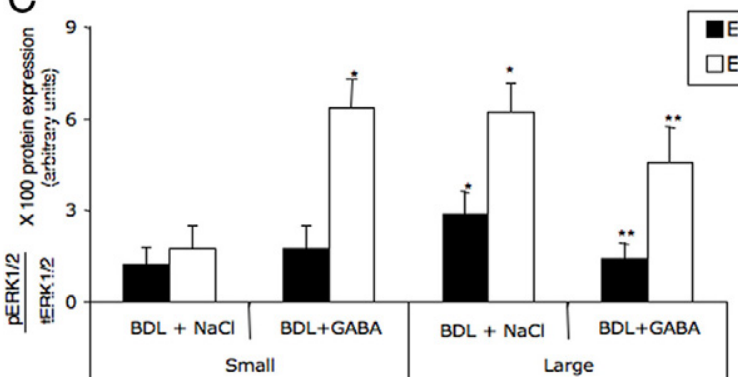

Figure 5. Evaluation of the membrane translocation (A) and phosphorylation $(\mathbf{B})$ of PKC $\beta$ II in small cholangiocytes from BDL rats treated with $\mathrm{NaCl}$ or GABA for 1 week. We observed enhanced membrane translocation (by immunofluorescence $[\mathbf{A}]$ ) and phosphorylation (by immunoblots $[\mathbf{B}]$ ) of PKC $\beta I I$ in small cholangiocytes from BDL GABA-treated rats compared with small cholangiocytes from BDL rats treated with $\mathrm{NaCl}$. A: Specific immunoreactivity of representative fields is shown in green; cell nuclei were stained with DAPI (blue). Bar $=200 \mu \mathrm{m}$. C: Evaluation of ERK1/2 phosphorylation in small and large cholangiocytes from BDL rats treated with $\mathrm{NaCl}$ or GABA for 1 week. After GABA administration to BDL rats, there was: (i) decreased phosphorylation of ERK1/2 in large cholangiocytes; and (ii) increased ERK2 (but not ERK1) phosphorylation in small cholangiocytes compared with small and large cholangiocytes from BDL rats treated with $\mathrm{NaCl}$. Data are mean \pm SEM of 8 blots. ${ }^{*} P<0.05$ versus small cholangiocytes from BDL rats treated with $\mathrm{NaCl}$ for 1 week. ${ }^{* *} P<0.05$ versus large cholangiocytes from BDL rats treated with $\mathrm{NaCl}$ for 1 week.

Parallel to other studies, ${ }^{6,9,32,38}$ secretin increased cAMP levels (Figure 7A) and $\mathrm{Cl}^{-}$efflux (Figure 7B) of large (but not small) BDL cholangiocytes compared with their corresponding basal values. In large cholangiocytes from BDL GABA-treated rats, there was a decrease in secretin-stimulated cAMP levels (Figure 7A) and $\mathrm{Cl}^{-}$efflux (Figure 7B) compared with their corresponding values of large BDL cholangiocytes. Small cholangiocytes from BDL GABA-treated rats de novo respond to secretin with increased cAMP levels (Figure $7 \mathrm{~A}$ ) and $\mathrm{Cl}^{-}$efflux (Figure 7B).
Intravenous infusion of secretin increased bile flow and bicarbonate secretion of BDI rats (Table 2). ${ }^{4,32,38,39}$ In $\mathrm{BDL}$ rats treated with GABA, secretin-stimulated bicarbonate rich choleresis was lower (although significant) compared with its corresponding values of $\mathrm{BDI}$ rats treated with $\mathrm{NaCl}$ (Table 2). The smaller but significant increase in secretin-stimulated choleresis (observed in BDL GABA-treated rats) is likely attributable to small proliferating cholangiocytes, which de novo respond to secretin in this model of large cholangiocyte damage.

\section{Discussion}

The findings of this study relate to the heterogeneous effects of GABA on the apoptotic, proliferative, and secretory functions of small and large cholangiocytes in cholestatic BDL rats. Chronic administration of GABA to BDL rats: (i) induced apoptosis of large cholangiocytes; (ii) reduced large cholangiocyte proliferation and IBDM by down-regulation of CAMP signaling; and (iii) decreased AC8 expression and reduced secretin-stimulated choleresis in large cholangiocytes. After GABA administration, small cholangiocytes: (i) were resistant to GABA-induced biliary apoptosis and de novo proliferate leading to an increased number of small ducts; (ii) displayed membrane translocation and phosphorylation of $\mathrm{Ca}^{2+}$-dependent $\mathrm{PKC} \beta \mathrm{ll}$; and (iii) de novo express SR, CFTR, $\mathrm{Cl}^{-} / \mathrm{HCO}_{3}^{-} \mathrm{AE} 2$ and $\mathrm{AC} 8$, and secrete water and electrolytes in response to secretin. During damage of large cholangiocytes, small ducts replenish the intrahepatic biliary tree by amplification of both $\mathrm{Ca}^{2+}$-dependent signaling and the acquisition of large cholangiocyte phenotypes.

We first demonstrated that both small and large cholangiocytes express $G_{A B A}, G A B A_{B}$, and $G A B A_{C}$ receptors at similar levels; the expression of the GABA receptors in small and large cholangiocytes did not change with GABA administration. These findings suggest that the heterogeneous effects of GABA on small and large cholangiocyte function are not attributable to the differential expression of these receptors in the two cell types. In our in vivo model it is difficult to pinpoint the specific receptors involved in GABA modulation of small and large cholangiocyte functions. Likely, these actions are mediated by all three GABA receptor subtypes. Our concept is supported by our previous in vitro studies ${ }^{21}$ in human cholangiocarcinoma cells showing that blocking of $G_{A B A}, G A B A_{B}$, and $G A B A_{C}$ receptors (by specific receptor antagonist) prevents GABA inhibition of cholangiocarcinoma proliferation.

Importantly, GABA administration induces large cholangiocyte damage only in rats with extrahepatic cholestasis, which can be explained based on the fact that: (i) GABA damages large ducts due to sensitization from obstructive cholestasis and consequent biliary/seric accumulation ${ }^{40}$; (ii) GABA damages only proliferating large cholangiocytes, and this is consistent with our previous findings in cholangiocarcinoma cells ${ }^{21}$; and (iii) GABA metabolism is dysregulated during liver damage induced by cholestasis. ${ }^{41}$ 

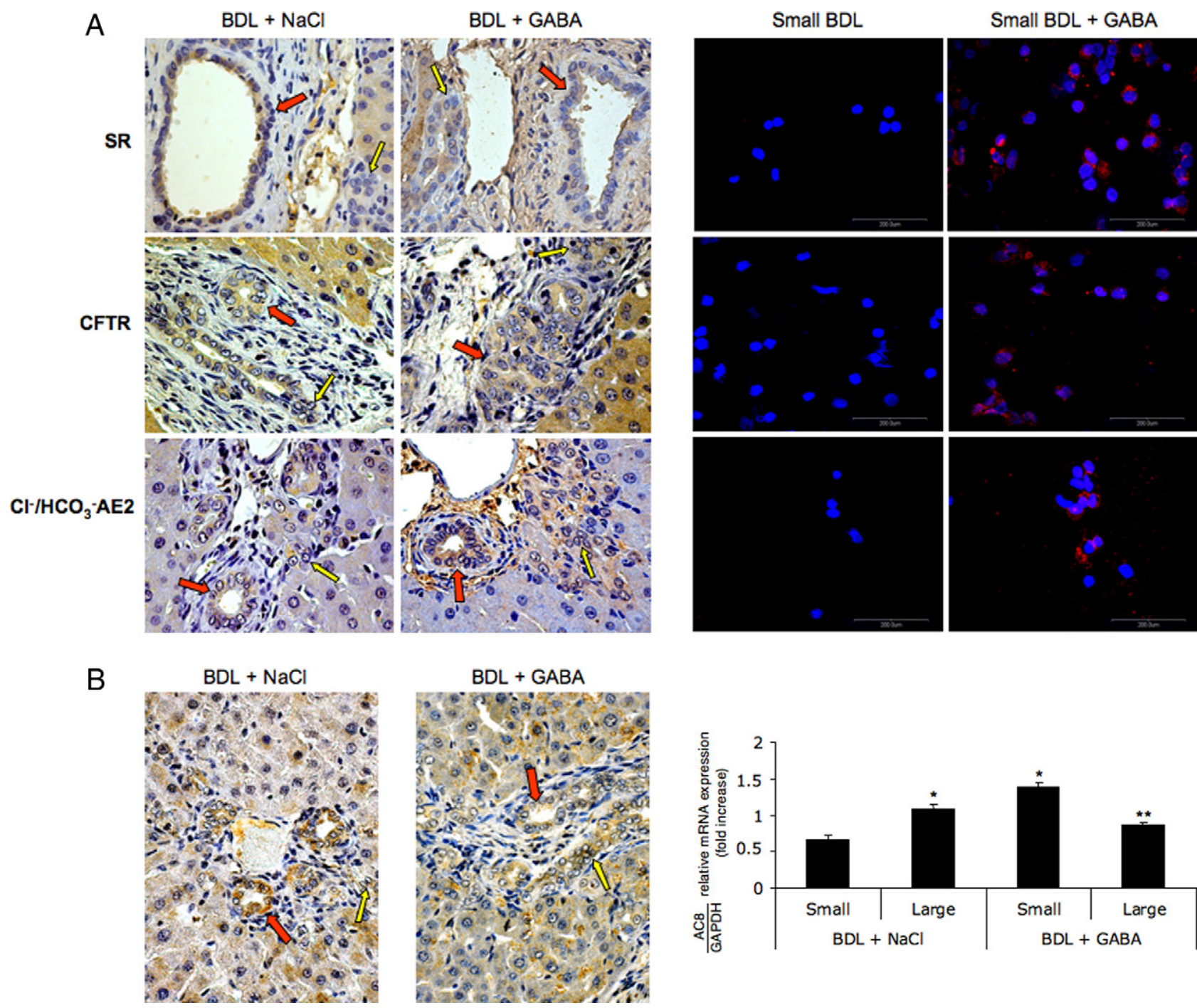

Figure 6. A: Representative immunohistochemistry for SR, CFTR, $\mathrm{Cl}^{-} / \mathrm{HCO}_{3}^{-} \mathrm{AE} 2$ and immunofluorescence in liver sections (left panel) and immunofluorescence in freshly isolated small cholangiocytes (right panel) from BDL rats treated with $\mathrm{NaCl}$ or GABA for 1 week. In liver sections, the protein for SR, CFTR, and $\mathrm{Cl}^{-} / \mathrm{HCO}_{3}^{-} \mathrm{AE} 2$ was expressed only by large (red arrows) bile ducts from BDL rats; no expression for SR, $\mathrm{CFTR}$ and $\mathrm{Cl}^{-} / \mathrm{HCO}_{3}^{-} \mathrm{AE} 2 \mathrm{was}$ seen in small (yellow arrows) bile ducts. In BDL rats treated with GABA, small bile ducts (yellow arrows) express de novo $\mathrm{SR}, \mathrm{CFTR}^{-}$and $\mathrm{Cl}^{-} / \mathrm{HCO}_{3}^{-} \mathrm{AE}^{2}$. Original magnification, $\times 40$. By immunofluorescence, small BDL cholangiocytes do not express SR, CFTR, and $\mathrm{Cl}^{-} / \mathrm{HCO}_{3}^{-} \mathrm{AE} 2$. After administration of GABA to BDL rats, small cholangiocytes express de novo SR, CFTR, and $\mathrm{Cl}^{-} / \mathrm{HCO}_{3}^{-} \mathrm{AE} 2$. Scale bar $=200 \mu \mathrm{m}$. B: Expression of AC8 was evaluated by immunohistochemistry in liver sections and real-time PCR in freshly isolated cholangiocytes from BDL rats treated with $\mathrm{NaCl}$ or GABA for 1 week. In liver sections from BDL rats treated with GABA, the expression of AC8 in liver sections seemed lower in large ducts (red arrows) and present de novo in small bile ducts (yellow arrows, left panel). By real-time PCR we demonstrated that: (i) AC8 was present in large and at lower levels in small BDL cholangiocytes; and (ii) AC8 mRNA expression decreased in large cholangiocytes and significantly increased in small cholangiocytes from BDL rats treated with GABA (right panel). Data are mean \pm SEM of 3 experiments. ${ }^{*} P<0.05$ versus small cholangiocytes from BDL rats treated with $\mathrm{NaCl}$ for 1 week. ${ }^{*} P<0.05$ versus large cholangiocytes from BDL rats treated with $\mathrm{NaCl}$ for 1 week.

A number of speculations and studies support the view that small cholangiocytes are more resistant than large cholangiocytes to hepatic injury/toxins. ${ }^{8,42}$ For example, the anti-apoptotic protein bcl-2 is expressed at higher levels by ductules and small bile ducts in normal human liver and human liver with cirrhosis and focal nodular hyperplasia. ${ }^{43}$ The higher resistance of small cholangiocytes to injury/toxins may be attributable to their primordial undifferentiated nature, whereas large cAMP-dependent cholangiocytes (more differentiated) are more susceptible to injury. Indeed, the presence of a larger nucleus and a smaller cytoplasm in small cholangiocytes $^{44}$ suggests the undifferentiated primitive nature of small bile ducts. ${ }^{42,44}$ On the other hand, large cholangio- cytes (displaying a larger cytoplasmic area) ${ }^{42,44}$ are more differentiated/senescent cells and more likely more susceptible to damage. However, these points are speculative, and further studies are necessary to support this view. ${ }^{42,44}$

The PKC signaling pathway modulates cell resistance to apoptosis in a number of systems. ${ }^{45,46}$ For example, the expression of $\mathrm{PKC} \beta \mathrm{l}$ confers resistance to tumor necrosis factor $\alpha$ and paclitaxel-induced apoptosis in HT-29 colon carcinoma cells. ${ }^{45}$ In this regard, the activation of GABA receptors stimulates PKC activity in hippocampal and cultured spinal neurons. ${ }^{47,48}$ Although our data do not demonstrate that the activation of $\mathrm{IP}_{3} / \mathrm{Ca}^{2+}$. dependent PKC signaling is the key factor for the higher 


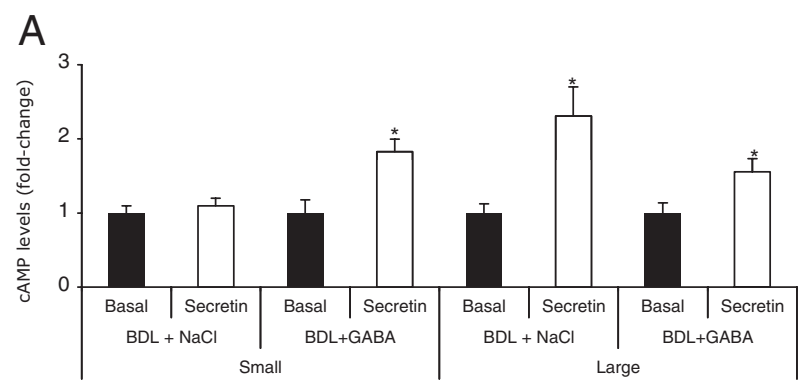

B

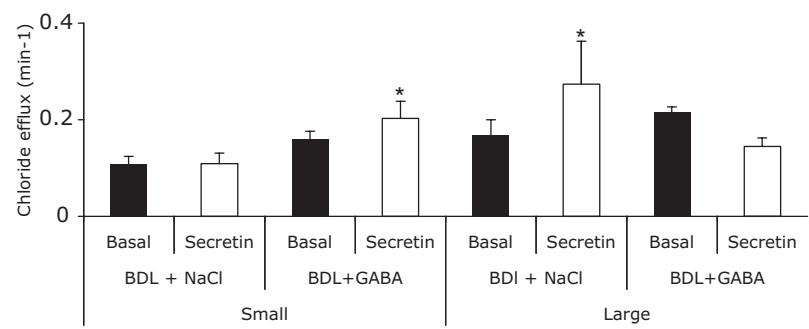

Figure 7. Measurement of basal and secretin-stimulated (A) cAMP levels and (B) $\mathrm{Cl}^{-}$efflux in small and large cholangiocytes from BDL rats treated with $\mathrm{NaCl}$ or GABA for 1 week. A: Secretin increased cAMP levels of large (but not small) BDL cholangiocytes compared with their corresponding basal values. In BDL rats treated with GABA, secretin did not increase cAMP levels in large cholangiocytes, but significantly increased cAMP levels of purified small cholangiocytes compared with small cholangiocytes from BDL rats treated with NaCl. Data are mean \pm SEM of six experiments. ${ }^{*} P<0.05$ versus the corresponding basal value. B: Secretin increased $\mathrm{Cl}^{-}$efflux of large (but not small) BDL cholangiocytes. In large cholangiocytes from BDL rats treated with GABA, secretin did not increase $\mathrm{Cl}^{-}$efflux. In small cholangiocytes from BDL GABA-treated rats, secretin induced a de novo increase in $\mathrm{Cl}^{-}$efflux. Data are mean \pm SEM of 6 experiments. ${ }^{*} P<0.05$ versus the corresponding basal value.

resistance of small cholangiocytes to GABA, they do suggest that activation of this signaling pathway is important for the activation of a "small bile duct compartment" to replenish the biliary epithelium during the damage of large bile ducts. ${ }^{14,15}$ The $\mathrm{IP}_{3} / \mathrm{Ca}^{2+}$-dependent signaling pathway and its cross talk with cAMP signaling are important regulators of small cholangiocyte functions. ${ }^{14} \mathrm{We}$ hypothesize that the trigger for the de novo activation of $\mathrm{Ca}^{2+} / \mathrm{PKC}$-dependent proliferation of small cholangiocytes is attributable to the down-regulation of CAMPdependent signaling in large cholangiocytes damaged by GABA treatment resulting in the absence of required functional capacity, which must be replenished by the activation of the small cholangiocyte compartment. In support of our hypothesis, studies have shown that GABA activity mediating cytosolic $\mathrm{Ca}^{2+}$ increases in developing

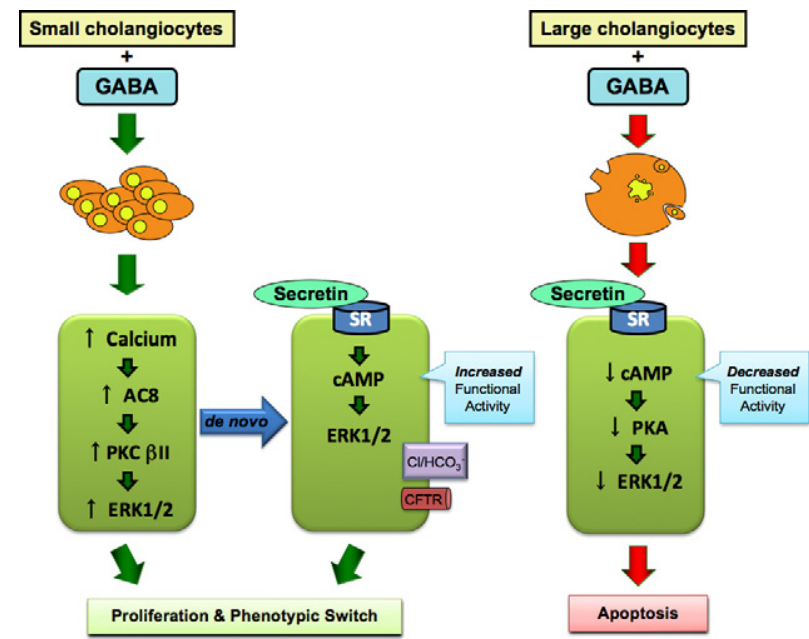

Figure 8. Working model of GABA-induced changes in small and large biliary proliferation/damage. Right: GABA stimulates a down-regulation of large cholangiocyte proliferation that results in the down-regulation of the functional capacity of cholangiocytes (ie, SR- $>$ CAMP- $>$ PKA- $>$ RK1/2 signaling mechanisms) and subsequently activates apoptosis. Left: GABA stimulates the proliferation of small cholangiocytes via the activation of calcium- $>$ AC8- $>$ PKC $\beta$ II$>$ ERK1/2-dependent signaling. In addition, GABA stimulates a phenotypic switch in small cholangiocytes resulting in the de novo expression of SR and the downstream cAMP->ERK1/2 signaling mechanisms. Also, GABA stimulates the de novo expression of CFTR and $\mathrm{Cl}^{-} / \mathrm{HCO}_{3}^{-}$exchanger, which a partners in cholangiocyte functional activity. AC indicates adenylyl cyclase; cAMP, cyclic adenosine $3^{\prime}, 5^{\prime}$-monophosphate; ERK1/2, extracellular signal-regulated kinase1/2; GABA, $\gamma$-aminobutyric acid; PKA, protein kinase A; PKC, protein kinase C; SR, secretin receptor.

neurons is triggered by changes (activation or inhibition) in CAMP-dependent signal transduction. ${ }^{49}$

The de novo acquisition of proliferative and secretory phenotypes of large cholangiocytes by small cholangiocytes is likely attributable to the $\mathrm{IP}_{3} / \mathrm{Ca}^{2+}$-dependent activation of $\mathrm{AC} 8$, a $\mathrm{Ca}^{2+}$-dependent $\mathrm{AC}$ isoform that plays a key role in the proliferative and secretory functions of large bile ducts. ${ }^{17}$ Nine $\mathrm{AC}$ isoforms exist in mammalian cells. ${ }^{50}$ All mammalian ACs are activated by GTP-bound stimulatory $\mathrm{G}$ protein $\alpha$ subunit $\left(\mathrm{G} \alpha_{\mathrm{s}}\right) .{ }^{50}$ Whereas activation of $\mathrm{G} \alpha$ s increases AC-mediated cAMP synthesis, inhibitory $G$ protein $\left(G \alpha_{\mathrm{i}}\right)$ inhibits all $A C$ isoforms except $\mathrm{AC}_{2}$ and $\mathrm{AC}_{4}{ }^{50}$ The effects of $\left[\mathrm{Ca}^{2+}\right]_{\mathrm{i}}$ are very diverse depending on the $A C$ isoform. ${ }^{50}$ The activities of $A C_{1}$, $\mathrm{AC}_{3}$, and $\mathrm{AC}_{8}$ are positively regulated by $\left[\mathrm{Ca}^{2+}\right]_{i}$ and calmodulin, whereas $\mathrm{AC}_{5}$ and $\mathrm{AC}_{6}$ are negatively modulated by $\left[\mathrm{Ca}^{2+}\right]_{1}{ }^{50}$ Several studies demonstrate the role of $\mathrm{AC}$ in the regulation of cholangiocyte functions. ${ }^{13,17,51}$ Changes in the activity of $\mathrm{G} \alpha_{\mathrm{s}}$ and $\mathrm{G} \alpha_{\mathrm{i}}$ protein subunits

Table 2. Measurement of Basal and Secretin-Stimulated Bile Flow and Bicarbonate Secretion

\begin{tabular}{|c|c|c|c|c|}
\hline Treatment & $\begin{array}{c}\text { Bile flow } \\
(\mu \mathrm{l} / \mathrm{min} / \mathrm{kg} \mathrm{BW}) \\
(\text { basal) }\end{array}$ & $\begin{array}{c}\text { Bile flow } \\
(\mu \mathrm{l} / \mathrm{min} / \mathrm{kg} \mathrm{BW}) \\
(\text { secretin })\end{array}$ & $\begin{array}{c}\text { Bicarbonate secretion } \\
(\mu \mathrm{Eq} / \mathrm{min} / \mathrm{kg} \mathrm{BW}) \\
(\text { basal) }\end{array}$ & $\begin{array}{c}\text { Bicarbonate secretion } \\
(\mu \mathrm{Eq} / \mathrm{min} / \mathrm{kg} \mathrm{BW}) \\
\text { (secretin) }\end{array}$ \\
\hline $\mathrm{BDI}+\mathrm{NaCl}$ & $120.3 \pm 13.0$ & $186.3 \pm 17.3^{*}$ & $5.2 \pm 0.6$ & $11.3 \pm 1.5^{\dagger}$ \\
\hline $\mathrm{BDI}+\mathrm{GABA}$ & $105.7 \pm 8.3$ & $139.5 \pm 11.1^{\text {*ł }}$ & $4.1 \pm 0.5$ & $6.7 \pm 0.5^{\dagger \S}$ \\
\hline
\end{tabular}

$\mathrm{BDI}$ indicates bile duct ligation. Data are mean \pm SEM of 5 experiments.

${ }^{\star} P<0.05$ versus its corresponding value of basal bile flow.

${ }^{+} P<0.05$ versus its corresponding value of basal bicarbonate secretion.

${ }^{\ddagger} P<0.05$ versus secretin-stimulated bile flow in BDI rats.

$\S p<0.05$ versus secretin-stimulated bicarbonate secretion in BDI rats. 
are associated with alteration of cholangiocyte growth of BDL rats. ${ }^{51}$ Increased cholangiocyte cAMP levels prevent bile duct damage by total vagotomy. ${ }^{13}$ Also, cross talk between the $\mathrm{IP}_{3} / \mathrm{Ca}^{2+} / \mathrm{PKC}$ pathway and $\mathrm{AC}$ plays a key role in the regulation of cholangiocyte functions. Gastrin inhibits cholangiocyte proliferation through activation of $\mathrm{Ca}^{2+}$-dependent PKC $\alpha{ }^{7}$ The D2 dopaminergic agonist, quinelorane, inhibits secretin-stimulated ductal secretion of $\mathrm{BDL}$ rats by activation of the $\mathrm{Ca}^{2+}$-dependent PKC $\gamma$, which leads to decreased PKA activity. ${ }^{32}$ The $\alpha-1$ adrenergic receptor, phenylephrine, increases secretinstimulated ductal secretion by activation of PKC $\alpha$ and $\mathrm{PKC} \beta \|{ }^{33}$

In summary, we have developed a novel in vivo model characterized by impaired function of large cAMP-dependent cholangiocytes (Figure 8). In this model, small cholangiocyte function is regulated by both the activation of $\mathrm{IP}_{3} / \mathrm{Ca}^{2+}$-dependent $\mathrm{PKC}$ signaling and the acquisition of large cholangiocyte functional markers to compensate for the damage of large ducts (Figure 8). In pathological conditions in which large CAMP-dependent bile ducts are damaged (eg, such as cystic fibrosis), ${ }^{5}$ the de novo activation of the $\mathrm{IP}_{3} / \mathrm{Ca}^{2+}-/ \mathrm{PKC}$-dependent small cholangiocyte compartment may be important compensatory mechanism for the replenishment of the biliary epithelium.

\section{References}

1. Alpini G, Glaser S, Robertson W, Rodgers RE, Phinizy JL, Lasater J, LeSage G: Large but not small intrahepatic bile ducts are involved in secretin-regulated ductal bile secretion. Am J Physiol Gastrointest Liver Physiol 1997, 272:G1064-G1074

2. Alpini G, Roberts S, Kuntz SM, Ueno Y, Gubba S, Podila PV, LeSage G, LaRusso NF: Morphological, molecular, and functional heterogeneity of cholangiocytes from normal rat liver. Gastroenterology 1996, 110:1636-1643

3. Glaser SS, Gaudio E, Miller T, Alvaro D, Alpini G: Cholangiocyte proliferation and liver fibrosis. Expert Rev Mol Med 2009, 11:e7

4. Alpini G, Lenzi R, Sarkozi L, Tavoloni N: Biliary physiology in rats with bile ductular cell hyperplasia. Evidence for a secretory function of proliferated bile ductules, J Clin Invest 1988, 81:569-578

5. Alpini G, Prall RT, LaRusso NF: The pathobiology of biliary epithelia. The Liver; Biology \& Pathobiology, 4E. Edited by Arias IM, Boyer JL, Chisari FV, Fausto N, Jakoby W, Schachter D, and Shafritz DA. Philadelphia, PA: Lippincott Williams \& Wilkins, 2001, pp. 421-435

6. Alpini G, Glaser S, Ueno Y, Pham L, Podila PV, Caligiuri A, LeSage G, LaRusso NF: Heterogeneity of the proliferative capacity of rat cholangiocytes after bile duct ligation. Am J Physiol Gastrointest Liver Physiol 1998, 274:G767-G775

7. Glaser S, Benedetti A, Marucci L, Alvaro D, Baiocchi L, Kanno N, Caligiuri A, Phinizy JL, Chowdhury U, Papa E, LeSage G, Alpini G: Gastrin inhibits cholangiocyte growth in bile duct-ligated rats by interaction with cholecystokinin-B/Gastrin receptors via D-myo-inositol 1,4,5-triphosphate-. $\mathrm{Ca}\left({ }^{2+}\right)$-, and protein kinase $\mathrm{C}$ alpha-dependent mechanisms, Hepatology 2000, 32:17-25

8. LeSage G, Glaser S, Marucci L, Benedetti A, Phinizy JL, Rodgers R, Caligiuri A, Papa E, Tretjak Z, Jezequel AM, Holcomb LA, Alpini G: Acute carbon tetrachloride feeding induces damage of large but not small cholangiocytes from BDL rat liver. Am J Physiol Gastrointest Liver Physiol 1999, 276:G1289-1301

9. Alpini G, Ulrich C, Roberts S, Phillips JO, Ueno Y, Podila PV, Colegio O, LeSage G, Miller LJ, LaRusso NF: Molecular and functional heterogeneity of cholangiocytes from rat liver after bile duct ligation. Am J Physiol Gastrointest Liver Physiol 1997, 272:G289-G297

10. Glaser SS, Gaudio E, Rao A, Pierce LM, Onori P, Franchitto A, Francis HL, Dostal DE, Venter JK, DeMorrow S, Mancinelli R, Carpino G,
Alvaro D, Kopriva SE, Savage JM, Alpini GD: Morphological and functional heterogeneity of the mouse intrahepatic biliary epithelium. Lab Invest 2009, 89:456-469

11. Kanno N, LeSage G, Glaser S, Alvaro D, Alpini G: Functional heterogeneity of the intrahepatic biliary epithelium. Hepatology 2000, 31:555-561

12. Martinez-Anso E, Castillo JE, Diez J, Medina JF, Prieto J: Immunohistochemical detection of chloride/bicarbonate anion exchangers in human liver. Hepatology 1994, 19:1400-1406

13. LeSage G, Alvaro D, Benedetti A, Glaser S, Marucci L, Baiocchi L, Eisel W, Caligiuri A, Phinizy JL, Rodgers R, Francis H, Alpini G: Cholinergic system modulates growth, apoptosis, and secretion of cholangiocytes from bile duct-ligated rats. Gastroenterology 1999, 117:191-199

14. Francis H, Glaser S, Demorrow S, Gaudio E, Ueno Y, Venter J, Dostal D, Onori P, Franchitto A, Marzioni M, Vaculin S, Vaculin B, Katki K, Stutes M, Savage J, Alpini G: Small mouse cholangiocytes proliferate in response to $\mathrm{H} 1$ histamine receptor stimulation by activation of the $\mathrm{IP}_{3} /$ CaMK I/CREB pathway. Am J Physiol Cell Physiol 2008, 295:C499-C513

15. Alpini G, Ueno Y, Glaser SS, Marzioni M, Phinizy JL, Francis H, Lesage G: Bile acid feeding increased proliferative activity and apical bile acid transporter expression in both small and large rat cholangiocytes. Hepatology 2001, 34:868-876

16. Banales JM, Arenas F, Rodriguez-Ortigosa CM, Saez E, Uriarte I, Doctor RB, Prieto J, Medina JF: Bicarbonate-rich choleresis induced by secretin in normal rat is taurocholate-dependent and involves AE2 anion exchanger. Hepatology 2006, 43:266-275

17. Strazzabosco M, Fiorotto R, Melero S, Glaser S, Francis H, Spirli C, Alpini G: Differentially expressed adenylyl cyclase isoforms mediate secretory functions in cholangiocyte subpopulation. Hepatology 2009, 50:244-252

18. Francis $H$, Franchitto A, Ueno $Y$, Glaser $S$, DeMorrow $S$, Venter J, Gaudio E, Alvaro D, Fava G, Marzioni M, Vaculin B, Alpini G: H3 histamine receptor agonist inhibits biliary growth of BDL rats by downregulation of the CAMP-dependent PKA/ERK1/2/ELK-1 pathway. Lab Invest 2007, 87:473-487

19. Watanabe M, Maemura K, Kanbara K, Tamayama T, Hayasaki H: GABA and GABA receptors in the central nervous system and other organs. Int Rev Cytol 2002, 213:1-47

20. Erlitzki R, Gong Y, Zhang M, Minuk G: Identification of gammaaminobutyric acid receptor subunit types in human and rat liver. Am J Physiol Gastrointest Liver Physiol 2000, 279:G733-G739

21. Fava G, Marucci L, Glaser S, Francis H, De Morrow S, Benedetti A, Alvaro D, Venter J, Meininger C, Patel T, Taffetani S, Marzioni M, Summers R, Reichenbach R, Alpini G: gamma-Aminobutyric acid inhibits cholangiocarcinoma growth by cyclic AMP-dependent regulation of the protein kinase A/extracellular signal-regulated kinase 1/2 pathway. Cancer Res 2005, 65:11437-11446

22. Minuk GY: Gamma-aminobutyric acid and the liver. Dig Dis 1993, 11:45-54

23. Martin C, Jacobi JS, Nava G, Jeziorski MC, Clapp C, Martinez de la Escalera G: GABA inhibition of cyclic AMP production in immortalized $\mathrm{GnRH}$ neurons is mediated by calcineurin-dependent dephosphorylation of adenylyl cyclase 9. Neuroendocrinology 2007, 85:257-266

24. Zhang M, Gong YW, Minuk GY: The effects of ethanol and gamma aminobutyric acid alone and in combination on hepatic regenerative activity in the rat. J Hepatol 1998, 29:638-641

25. Rutenburg AM, Kim H, Fischbein JW, Hanker JS, Wasserkrug HL, Seligman AM: Histochemical and ultrastructural demonstration of gamma-glutamyl transpeptidase activity. J Histochem Cytochem 1969, 17:517-526

26. DeMorrow S, Francis H, Gaudio E, Ueno Y, Venter J, Onori P, Franchitto A, Vaculin B, Vaculin S, Alpini G: Anandamide inhibits cholangiocyte hyperplastic proliferation via activation of thioredoxin 1/redox factor 1 and AP-1 activation. Am J Physiol Gastrointest Liver Physiol 2008, 294:G506-G519

27. DeMorrow S, Glaser S, Francis H, Venter J, Vaculin B, Vaculin S, Alpini G: Opposing actions of endocannabinoids on cholangiocarcinoma growth: recruitment of Fas and Fas ligand to lipid rafts. J Biol Chem 2007, 282:13098-13113

28. Marutha Ravindran CR, Mehta AK, Ticku MK: Effect of chronic administration of ethanol on the regulation of the delta-subunit of GABA(A) receptors in the rat brain. Brain Res 2007, 1174:47-52 
29. Grampp T, Notz V, Broll I, Fischer N, Benke D: Constitutive, agonistaccelerated, recycling and lysosomal degradation of GABA(B) receptors in cortical neurons. Mol Cell Neurosci 2008, 39:628-637

30. Yang L, Nakayama Y, Hattori N, Liu B, Inagaki C: GABAC-receptor stimulation activates CAMP-dependent protein kinase via A-kinase anchoring protein 220. J Pharmacol Sci 2008, 106:578-584

31. Sheng G, Guo J, Warner BW: Epidermal Growth Factor Receptor Signaling Modulates Apoptosis via p38\{alpha\} MAPK-Dependent Activation of Bax in Intestinal Epithelial Cells. Am J Physiol Gastrointest Liver Physiol 2007, 293:G599-G606

32. Glaser S, Alvaro D, Roskams T, Phinizy JL, Stoica G, Francis H, Ueno Y, Barbaro B, Marzioni M, Mauldin J, Rashid S, Mancino MG, LeSage G, Alpini G: Dopaminergic inhibition of secretin-stimulated choleresis by increased PKC-gamma expression and decrease of PKA activity. Am J Physiol Gastrointest Liver Physiol 2003, 284:G683-G694

33. LeSage G, Alvaro D, Glaser S, Francis H, Marucci L, Roskams T, Phinizy JL, Marzioni M, Benedetti A, Taffetani S, Barbaro B, Fava G, Ueno Y, Alpini G: Alpha-1 adrenergic receptor agonists modulate ductal secretion of $\mathrm{BDL}$ rats via $\mathrm{Ca}\left({ }^{2+}\right)$ - and PKC-dependent stimulation of cAMP. Hepatology 2004, 40:1116-1127

34. Francis $\mathrm{H}$, Glaser $\mathrm{S}$, Ueno $\mathrm{Y}$, LeSage G, Marucci L, Benedetti A Taffetani S, Marzioni M, Alvaro D, Venter J, Reichenbach R, Fava G, Phinizy JL, Alpini G: CAMP stimulates the secretory and proliferative capacity of the rat intrahepatic biliary epithelium through changes in the PKA/Src/MEK/ERK 1/2 pathway. J Hepatol 2004, 41:528-537

35. Francis H, LeSage G, DeMorrow S, Alvaro D, Ueno Y, Venter J, Glaser S, Mancino MG, Marucci L, Benedetti A, Alpini G: The alpha2-adrenergic receptor agonist UK 14,304 inhibits secretin-stimulated ductal secretion by downregulation of the CAMP system in bile duct-ligated rats. Am J Physiol Cell Physiol 2007, 293:C1252-C1262

36. Fitz JG, Basavappa S, McGill J, Melhus O, Cohn JA: Regulation of membrane chloride currents in rat bile duct epithelial cells. J Clin Invest 1993, 91:319-328

37. Masada N, Ciruela A, Macdougall DA, Cooper DM: Distinct mechanisms of regulation by $\mathrm{Ca}^{2+} /$ calmodulin of type 1 and 8 adenylyl cyclases support their different physiological roles. J Biol Chem 2009, 284:4451-4463

38. LeSage G, Marucci L, Alvaro D, Glaser S, Benedetti A, Marzioni M, Patel T, Francis $H$, Phinizy JL, Alpini G: Insulin inhibits secretininduced ductal secretion by activation of PKC alpha and inhibition of PKA activity. Hepatology 2002, 36:641-651

39. Tietz PS, Alpini G, Pham LD, LaRusso NF: Somatostatin inhibits secretin-induced ductal hypercholeresis and exocytosis by cholangiocytes. Am J Physiol Gastrointest Liver Physiol 1995, 269: G110-G118

40. Nathwani RA, Kaplowitz N: Drug hepatotoxicity. Clin Liver Dis 2006, 10:207-217, vii

41. Levy LJ, Losowsky MS: Plasma gamma aminobutyric acid concentrations provide evidence of different mechanisms in the pathogenesis of hepatic encephalopathy in acute and chronic liver disease. Hepatogastroenterology 1989, 36:494-498

42. Marzioni M, Glaser SS, Francis H, Phinizy JL, LeSage G, Alpini G: Functional heterogeneity of cholangiocytes. Semin Liver Dis 2002, 22:227-240

43. Charlotte F, L'Hermine A, Martin N, Geleyn Y, Nollet M, Gaulard P, Zafrani ES: Immunohistochemical detection of bcl-2 protein in normal and pathological human liver. Am J Pathol 1994, 144:460-465

44. Benedetti A, Bassotti C, Rapino K, Marucci L, Jezequel AM: A morphometric study of the epithelium lining the rat intrahepatic biliary tree. J Hepatol 1996, 24:335-342

45. Cesaro P, Raiteri E, Demoz M, Castino R, Baccino FM, Bonelli G Isidoro C: Expression of protein kinase $\mathrm{C}$ beta1 confers resistance to TNFalpha- and paclitaxel-induced apoptosis in HT-29 colon carcinoma cells. Int J Cancer 2001, 93:179-184

46. Shankar E, Sivaprasad U, Basu A: Protein kinase C epsilon confers resistance of MCF-7 cells to TRAIL by Akt-dependent activation of Hdm2 and downregulation of p53. Oncogene 2008, 27:3957-3966

47. Dutar P, Nicoll RA: Pre- and postsynaptic GABAB receptors in the hippocampus have different pharmacological properties. Neuron 1988, 1:585-591

48. Taniyama K, Niwa M, Kataoka Y, Yamashita K: Activation of protein kinase $\mathrm{C}$ suppresses the gamma-aminobutyric acidB receptor-mediated inhibition of the vesicular release of noradrenaline and acetylcholine. J Neurochem 1992, 58:1239-1245

49. Obrietan $\mathrm{K}$, van den Pol AN: GABA activity mediating cytosolic $\mathrm{Ca}^{2+}$ rises in developing neurons is modulated by cAMP-dependent signal transduction. J Neurosci 1997, 17:4785-4799

50. Hasegawa G, Kumagai S, Yano M, Wang YG, Kobayashi Y, Saito Y: 12(S)-Hydroxyeicosatetraenoic acid induces CAMP production via increasing intracellular calcium concentration. FEBS Lett 2003, $554: 127-132$

51. Rodriguez-Henche N, Guijarro LG, Couvineau A, Carrero I, Arilla E, Laburthe M, Prieto JC: $\mathrm{G}$ proteins in rat liver proliferation during cholestasis. Hepatology 1994, 20:1041-1047 